\title{
Review
}

\section{Migraine: Calcium Channels and Glia}

\author{
Marta Kowalska ${ }^{1}$, Michał Prendecki ${ }^{1}$, Thomas Piekut ${ }^{1}$, Wojciech Kozubski ${ }^{2}$ and Jolanta Dorszewska ${ }^{1, *}$ (D) \\ 1 Laboratory of Neurobiology, Department of Neurology, Poznan University of Medical Sciences, \\ 49 Przybyszewskiego St., 60-355 Poznan, Poland; martak_89@o2.pl (M.K.); mprendecki@ump.edu.pl (M.P.); \\ 82820@student.ump.edu.pl (T.P.) \\ 2 Chair and Department of Neurology, Poznan University of Medical Sciences, 49 Przybyszewskiego St., \\ 60-355 Poznan, Poland; wkozubski@ump.edu.pl \\ * Correspondence: dorszewskaj@yahoo.com or jolanta.dorszewska@ump.edu.pl; Tel.: +48-61-86-91-439; \\ Fax: +48-61-86-91-697
}

Citation: Kowalska, M.; Prendecki, M.; Piekut, T.; Kozubski, W.; Dorszewska, J. Migraine: Calcium Channels and Glia. Int. J. Mol. Sci. 2021, 22, 2688. https://doi.org/ $10.3390 /$ ijms 22052688

Academic Editor: Agata Adamczyk

Received: 23 January 2021

Accepted: 3 March 2021

Published: 7 March 2021

Publisher's Note: MDPI stays neutral with regard to jurisdictional claims in published maps and institutional affiliations.

Copyright: (c) 2021 by the authors. Licensee MDPI, Basel, Switzerland. This article is an open access article distributed under the terms and conditions of the Creative Commons Attribution (CC BY) license (https:// creativecommons.org/licenses/by/ $4.0 /)$.
Abstract: Migraine is a common neurological disease that affects about $11 \%$ of the adult population. The disease is divided into two main clinical subtypes: migraine with aura and migraine without aura. According to the neurovascular theory of migraine, the activation of the trigeminovascular system (TGVS) and the release of numerous neuropeptides, including calcitonin gene-related peptide (CGRP) are involved in headache pathogenesis. TGVS can be activated by cortical spreading depression (CSD), a phenomenon responsible for the aura. The mechanism of CSD, stemming in part from aberrant interactions between neurons and glia have been studied in models of familial hemiplegic migraine (FHM), a rare monogenic form of migraine with aura. The present review focuses on those interactions, especially as seen in FHM type 1, a variant of the disease caused by a mutation in $C A C N A 1 A$, which encodes the $\alpha 1 \mathrm{~A}$ subunit of the $\mathrm{P} / \mathrm{Q}$-type voltage-gated calcium channel.

Keywords: migraine; FHM; cortical spreading depression; CACNA1A; CaV2.1; glia

\section{Review Criteria}

Articles discussed in this Review were identified by PubMed searches for the years 1990 to the present, using the search terms "migraine and calcium", "migraine and calcium signaling", "CACNA1A mutations", "migraine and CaV2.1", "migraine and glia", "glia and calcium in migraine" among others. The reference lists of identified papers were searched for further relevant articles, and related citations for identified papers as listed on the PubMed site were also evaluated.

\section{Migraine}

Migraine is a common primary headache disorder that affects $11 \%$ of adults worldwide. The prevalence of disease is three times higher in women (15-18\%) than in men [1]. Two peaks of incidence have been observed among migraine sufferers: the first after puberty and the second in adults aged $35-40$ years [2]. In $25 \%$ of cases, the migraine begins in childhood. According to World Health Organization (WHO) data 324 million people struggle with this disease and 3000 migraine attacks occur every day per one million people [3]. The Global Burden of Disease study listed migraine as the third of 289 of the most prevalent diseases worldwide [4].

The disease is divided into two main clinical subtypes: migraine with aura (MA) and migraine without aura (MO). Aura is defined as spreading neurological disturbances such as visual, sensory or motor symptoms that precede or accompany the headache. The most common clinical features of aura are visual changes including flashing scotoma, loss of vision, and visual hallucinations. More rarely, numbness, tingling, ataxia, aphasia, confusion, ringing in the ears, and dizziness occur. MO, also called common migraine, occurs in two-thirds of patients. The migraine pain lasts $4-72 \mathrm{~h}$, is moderate or severe, unilateral, throbbing, worsens with physical activity, and is often accompanied by photophobia, 
phonophobia, and nausea/vomiting [5-8]. Migraine is also classified according to the frequency of attacks into chronic, lasting at least 15 days each month, and milder, episodic forms. Chronic migraine, sometimes called transformed, affects about $2 \%$ of the population and occurs after many years of a typical, episodic migraine. The tendency to transformation may be increased by coexisting depression, anxiety, panic attacks, social phobia and by other pain syndromes $[4,9]$.

\subsection{The Pathogenesis of Migraine}

Migraine pathophysiology involves complex mechanisms in which the trigeminovascular system (TGVS) and cortical spreading depression (CSD) play an important role (Figure 1) [10]. The TGVS is a major afferent pathway for pain from cranial vessels and dura mater and consists of neurons whose bodies reside in the trigeminal ganglion (TG) and upper cervical dorsal root ganglia [11]. The TG consists mainly of primary afferent neurons and glial cells. As it is not protected by the blood-brain barrier (BBB), neuropeptides released in the TG, such as calcitonin gene-related peptide (CGRP), substance P (SP), and neurokinin A (NKA) thereby enter systemic circulation [12].

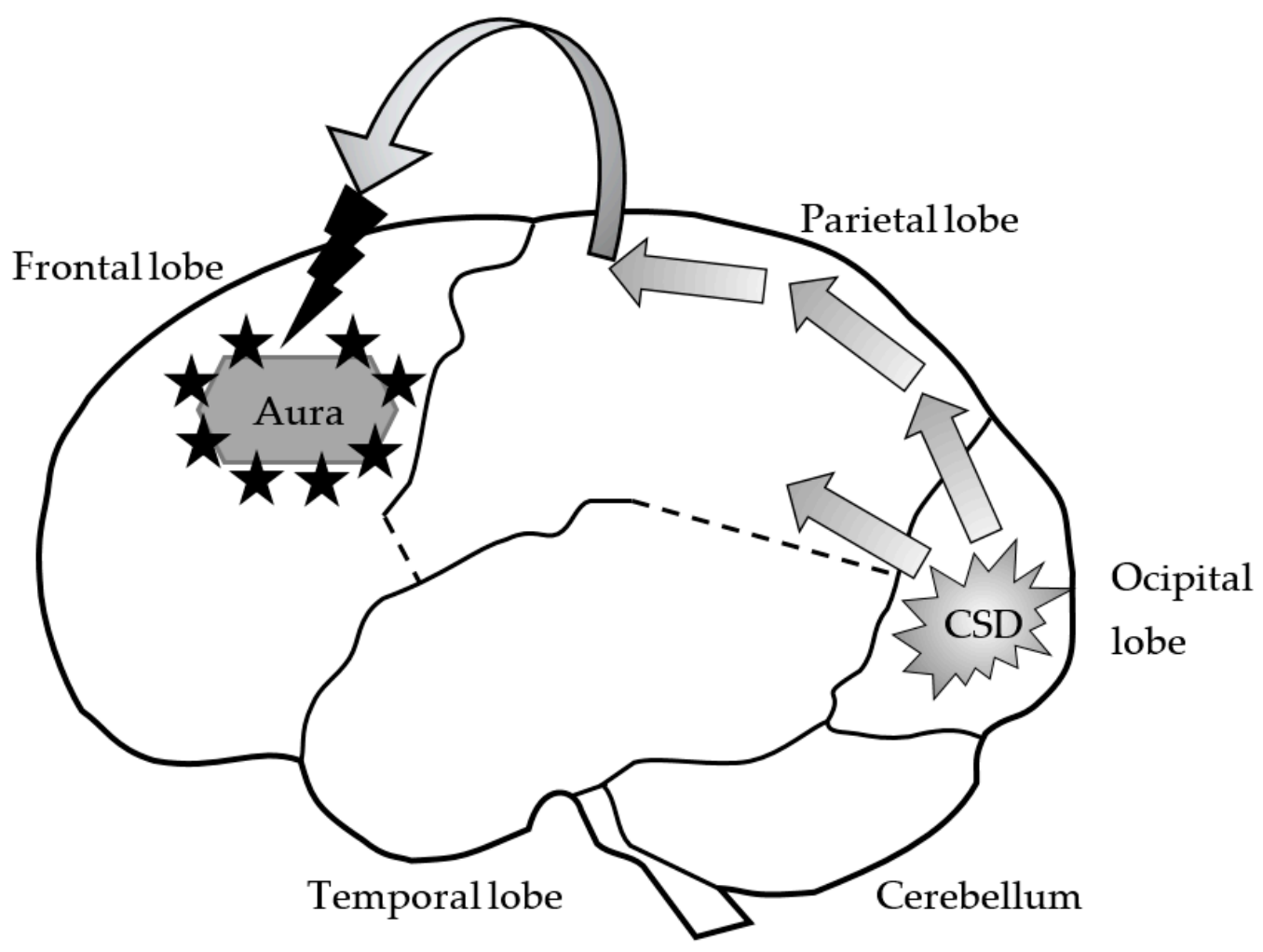

Figure 1. Cortical spreading depression. Changes in central nervous system flow that may induce a migraine attack may be associated with the occurrence of spreading cortical spreading depression (CSD). Oligemia (reduced vascular flow) begins in the occipital and parieto-occipital areas, then moves through the cerebral cortex and stops at the medial and lateral sulcus. In some patients, CSD may extend to the frontal lobes. This phenomenon seems to be responsible for the aura formation during a migraine headache.

CSD consists of a slow wave of depolarization followed by longer-lasting suppression of neurons and glial cells. It is characterized by increased $\mathrm{K}^{+}$and decreased $\mathrm{Na}^{+}$ extracellular levels and changes in the gradients of other ions, e.g., $\mathrm{Mg}^{2+}, \mathrm{Zn}^{2+}, \mathrm{Cl}^{-}$[13]. Although the direct triggers for spontaneous CSD, especially in migraine, are unknown, elevated extracellular concentrations of $\mathrm{K}^{+}$and glutamate are thought to cause dendritic depolarization in a non-synaptic manner. Animal model studies have suggested that CSD is the mechanism underlying visual aura in migraine [14], a conclusion corroborated by 
neuroimaging studies which have linked electrical changes in the visual cortex during aura (geometrical shapes, scintillating scotoma) with the pattern of CSD [15].

According to the neurovascular theory of migraine, headache is a result of TGVS activation by CSD. CSD triggers the pain pathway via activation of trigeminal afferents which transmit information to the TG, the caudal trigeminal nucleus (TNC) and ultimately to cortical and brainstem structures involved in pain processing (Figure 1). Activation of the TGVS leads to local release of vasodilators such as CGRP, SP, NKA, NO, and a transient increase in cortical blood flow followed by sustained flow decrease [16-18].

\subsection{Migraine Disturbs Calcium Homeostasis}

Currently, it is believed that the distribution of various ions between intracellular and extracellular compartments is altered in migraine. As aforementioned, increased extracellular $\mathrm{K}^{+}$and decreased $\mathrm{Na}^{+}$promote CSD [13]. Calcium levels are also altered in the course of migraine [19]. These findings have led scientists to argue that migraine is a channelopathy. It is believed that mutations in genes encoding channel subunits or proteins modulating channel function lead to ionic disturbances in synapses, thereby increasing susceptibility to CSD and migraines [20-22].

Dysregulated calcium currents as seen in the context of migraine derive largely from aberrant function of the high-voltage activated calcium channel CaV2.1 and the transient receptor potential ankyrin channel, encoded by the genes CACNA1A and TRPA1, respectively (Figure 2) $[20,21,23]$. Localized presynaptically, the CaV2.1 channel plays an important role in communication between neurons by controlling the release of neurotransmitters [24]. Certain mutations in the CACNA1A gene result in increased activation of CaV2.1, which in turn leads to increased intracellular $\mathrm{Ca}^{2+}[20-22,25]$. TRPA1, a nonselective $\mathrm{Ca}^{2+}$-permeable ion channel, belongs to a family of transient potential receptors serving as modalities for the sensation of environmental stimuli. Expressed on A $\delta$ and $C$ afferent fibers, TRPA1 transduces pain from a broad array of irritants, both food (e.g., allyl isothiocyanate in mustard) and chemical (e.g., formaldehyde) and is thought to be implicated in the pathogenesis of headache $[23,26]$. Although the mechanisms whereby environmental irritants cause headache remain largely unknown, activation of TRPA1 by mechanical or chemical stimuli causes CGRP to be released and increases cerebral blood flow [26,27].

Beyond CaV2.1, other voltage-gated calcium channels (VGCCs) may play a role in the pathogenesis of migraine [28]. Interestingly, while presynaptic CaV2 channels might be expected to drive the release of CGRP associated with migraine, the high-voltage activated and canonically postsynaptic $\mathrm{CaV} 1$ channels and the low-voltage activated $\mathrm{CaV} 3$ channels $[24,29]$ were both also found to regulate CGRP release in the trigeminal ganglion, as evidenced through pharmacological blockade experiments [30]. Further, by correlating the genetic codependency of $\mathrm{Ca}^{2+}$ levels with the risk of migraine headache, Yin et al. [31] showed that migraine can be linked to inherited hypercalcemia.

Several classes of drugs are currently used in the treatment and prevention of migraine, including angiotensin converting enzyme inhibitors, angiotensin receptor blockers, $\mathrm{Ca}^{2+}$ channel blockers, serotonin antagonists, alpha adrenergic agonists, and NMDA receptor antagonists [32]. $\mathrm{Ca}^{2+}$ channel blockers exert their effect by blocking $\mathrm{Ca}^{2+}$ influx into vascular smooth muscle and cardiac muscle cells during membrane depolarization, leading to a reduction in blood pressure. Their main application is in the treatment of arterial hypertension and angina and while used also for migraine pain relief therapy, they may themselves result in side effects such as headaches and dizziness. As $\mathrm{Ca}^{2+}$ channel blockers are specific for different VGCCs and vary broadly in their pharmacologic effects, the development of therapeutics that selectively target those channels which are centrally expressed and implicated in migraine pathogenesis is of high research value. 


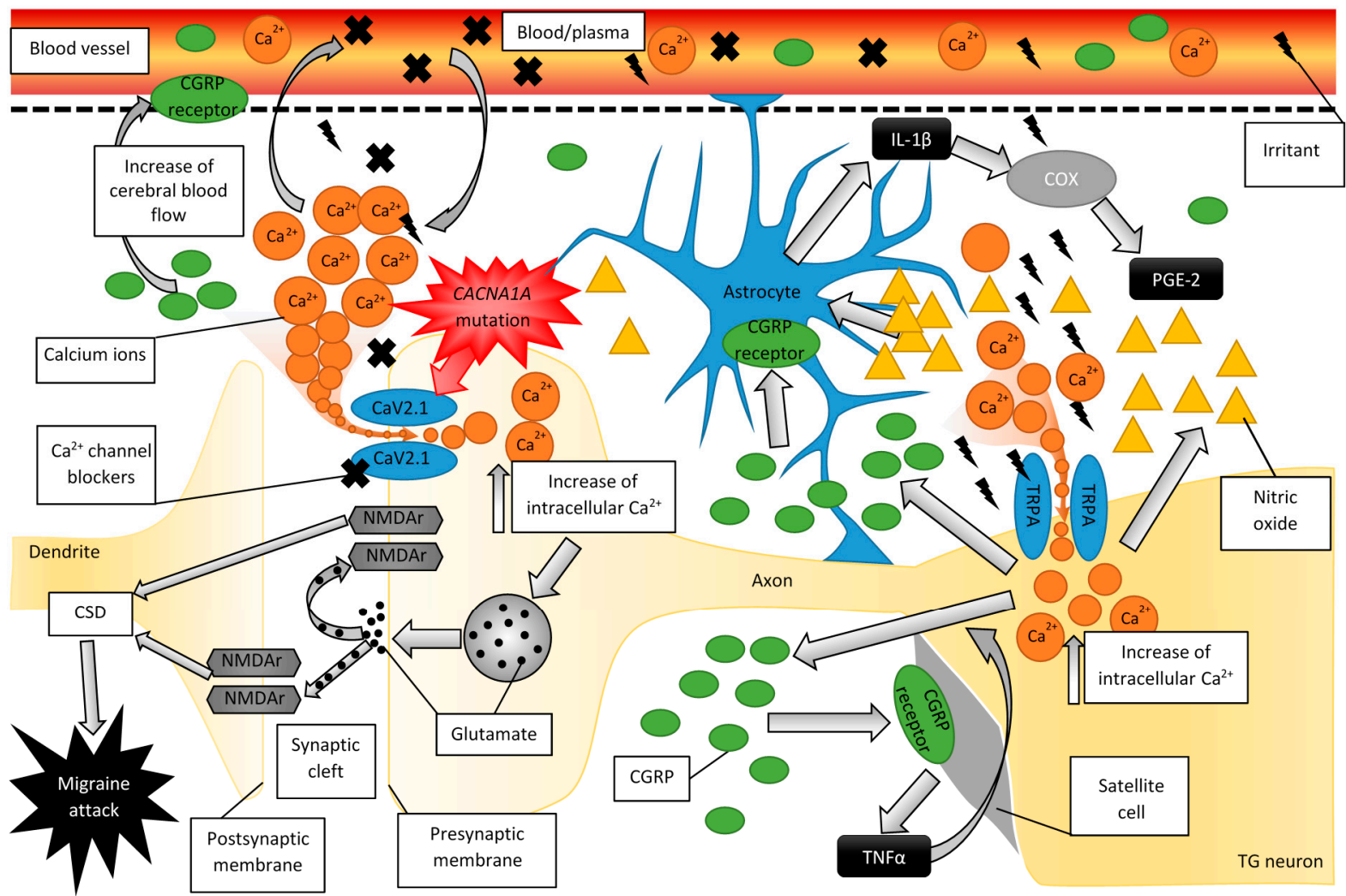

Figure 2. Induction of migraine attack due to sensitization of trigeminal ganglia and disturbed glutamatergic release. TRPA1 receptors in sensory neurons in trigeminal ganglia (TG) activate under environmental irritants taken by inhalation, ingestion or in an unknown mechanism. Activation of the TRPA1 receptor stimulates the release of calcitonin gene-related peptide (CGRP) that may enter bloodstream during migraine attack. CGRP receptor is expressed by majority on the neurons forming myelinated TG A-fibers, as well as on smooth muscles of dura's vasculature. CGRP receptor stimulation increases blood flow. Besides CGRP, activated TG neurons secrete nitric oxide (NO). These mediators stimulate further the surrounding glial cells to produce interleukin-1 $\beta$ (IL-1 $\beta$ ) that in turn leads to increased activity of cyclooxygenase (COX), associated with production of proinflammatory prostaglandin E2 (PGE2). This phenomenon may be one of foundations of the TG neurons sensitization. Subsequently, CGRP released by TG neurons may also promote release of tumor necrosis factor- $\alpha($ TNF- $\alpha)$ in the glial satellite cells. That may cause a positive feedback loop of further TG-neuronal synthesis and secretion of CGRP. Furthermore, the released TNF- $\alpha$ may itself sensitize TG neurons and inflict overproduction of various other proinflammatory cytokines. Activation of TRPA channels increase the intracellular calcium ion levels $\left(\mathrm{Ca}^{2+}\right)$, similarly to L-type of Voltage Gated Calcium Channel (CaV2.1). Mutations in CACNA1A gene lead to enhanced Ca ${ }^{2+}$ currents. The enhanced $\mathrm{Ca}^{2+}$ influx lead to excitation-inhibition imbalance and enhanced glutamate release. The interaction between glutamate and pre- and postsynaptic glutamate NMDA receptors (NMDAr) may facilitate the cortical spreading depression (CSD) - believed as one of the causes of migraine attack. $\mathrm{Ca}^{2+}$ channel blockers affect the CaV2.1 channels and reduce excessive $\mathrm{Ca}^{2+}$ influx to the cells, normalizing glutamate release and thus may be also used in the treatment of migraine headaches.

\subsection{Experimental Evidence for the Role of CGRP in Migraine}

Literature reports suggest that CGRP may be a principal mediator of migraine in the TGVS [33]. The CGRP neuropeptide is expressed in nearly half of TG neurons, mostly in those forming unmyelinated nociceptive C-fibers. Conversely, the CGRP receptor is expressed by the majority of neurons forming the second class of TG fibers, myelinated A-fibers, as well as in smooth muscle tissue of the dura's vasculature [34]. There are two isoforms of CGRP, differing by three amino acids and the tissues where they are predominantly expressed. $\alpha$-CGRP is most abundant in the CNS and peripheral nerves of the somatosensory system, while the $\beta$-isoform is mostly present in the enteric nervous system and motor neurons [35]. The connection between CGRP and migraine has been documented quite well, however a clear mechanistic explanation for its role in the disease 
is lacking. It has been shown that CGRP administered intravenously induces a delay in the onset of a migraine attack in individuals with a history of migraine, but not in healthy controls. Notably, CGRP is not allogenic, since it does not provoke any somatic effects beyond headache [36] or an erythemic flare in the skin [37]. Interestingly, while CGRP infusion was shown to induce delayed headache in patients suffering from migraines, the neuromodulator did not cause premonitory symptoms, such as aura, suggesting attacks may be periphery-derived [38]. Moreover, CGRP is likely released into the bloodstream during a migraine attack, especially seeing how it has been detected in samples drawn from the jugular vein of sufferers [16,36-41]. Increased CGRP levels have also been observed between attacks in migraine patients as compared to controls. As such, CGRP may be associated with the chronic form of migraine, particularly given that in this disease subtype, the level of the neuropeptide was significantly higher than in episodic migraine patients [41]. The level of CGRP was also shown to be elevated in a nitroglycerin model of migraine, which responded to the triptan family of drugs commonly used as abortive therapy for the disease [42]. Specifically, administration of sumatriptan significantly reduced CGRP release from the TG, and secondarily caused significant decline of blood CGRP levels, along with reduced headache intensity. Another study evaluating rizatriptan correlated higher salivary CGRP levels with better response to the drug, thereby potentially providing a way for identifying promising patient candidates for specific anti-migraine therapies [43]. Taken together, the above studies indicate a pivotal role of CGRP in TGVS regulation of migraine attacks and indeed, CGRP is becoming a target point for emerging therapies. Several clinical studies tackling the CGRP pathway for relieving migraine showed promising results and involve CGRP antagonists as well as antibodies against the CGRP receptor and CGRP itself. The CGRP antagonists (BI 44,370 TA, MK-3207, olcegepant, imegepant, telcagepant, and ubrogepant) were shown to be effective as migraine abortive therapy [44-50]. Further, various antibodies against CGRP: eptinezumab, fremanezumab and galcanezumab proved to be effective for various forms of migraine, while retaining a safe therapeutic profile [51-56]. Similarly promising results were noted for erenumab (AMG 334), a monoclonal antibody against the CGRP receptor $[57,58]$.

\subsection{The Role of CGRP and Glial Cells in Migraine Pathogenesis}

Since the mid-1980s, it has been postulated that CGRP integrally influences the neuronglial interactions associated with migraine pain propagation [33]. CGRP is likely released from TG neurons in response to migraine triggers e.g., stress and hypoxia communicated via afferents from the periphery [59]. Moreover, although a direct link between CGRP and CSD has not been established, increased extracellular $\mathrm{K}^{+}$, seen as a condition for the latter, may drive CGRP release (Figure 2) [25]. CGRP triggers NO production which in turn leads to increased expression of CGRP and neuronal nitric oxide synthase (nNOS) [60] creating a positive feedback loop that promotes sensitization of primary peripheral trigeminal fibers and activity-independence of central second-order neurons [61]. These mediators further stimulate the surrounding glial cells, termed satellite cells, to produce interleukin- $1 \beta$ (IL$1 \beta$ ) which promotes increased cyclooxygenase activity, such that is tied to the production of proinflammatory prostaglandin E2 (PGE2) [62-64]. Similarly, CGRP-stimulated satellite cells release TNF $\alpha$, which has also been implicated in the positive feedback driving TG neuron sensitization, both directly and via the release of additional proinflammatory cytokines $[65,66]$. Indeed, the literature suggests that the secretion of CGRP from one type of TG neuron may induce cytokine secretion in other TG neurons as well as in adjacent satellite glial cells $[62,67,68]$. It is the TG satellite cell-mediated up-regulation of specific proalgogenic receptors combined with long-term sensitization of TG neurons that enhances pain [61]. Further corroborating this hypothesis, a study by Cady et al. [69] demonstrated that CGRP injection into the rat temporomandibular joint led to formation of the activated phenotype of both microglia and astrocytes in the TNC. This phenomenon is thought to be responsible for maintaining the central sensitization of neurons involved in pain perception and is likely implicated in the progression from episodic to chronic migraine [61]. 
Conversely, Cornelison et al. [70] showed that administering CGRP into the cisternae of the rat brain lead to activation of astrocytes but not microglia, as the authors observed no change in the level of the microglial marker ionized calcium-binding adapter molecule (Iba1), but did note enhanced expression of the astrocytic markers glial fibrillary acidic protein (GFAP) and protein kinase A (PKA).

Several inhibitors of glial cell activation including naltrexone, naloxone, minocycline and ibudilast have been proposed as prophylactics against migraine [71]. However, clinical trial results published by Kwok et al. [66] demonstrated similar attack frequency and intensity, as well as no changes in allodynia, quality of life, medication use, or the secondary measures of headache in chronic migraine patients who received ibudilast for eight weeks. Still, comparable studies have not been performed in patients with episodic migraine, leaving the question of whether ibdulast could prove effective in preventing the transformation of episodic migraine into a chronic disorder unanswered.

The interactions between activated trigeminal neurons and adjacent glial cells which are mediated by gap junctions and paracrine signaling are likely also connected to the development of peripheral sensitization within the TG and other elements of migraine pathogenesis [64]. It is hypothesized that elevated expression and activity of gap junctions and pannexin (Panx) channels at the level of the sensory ganglia and TG neurons in inflammatory and neuropathic models of pain may lead to augmented excitation of sensory neurons. It is also worth noting, the gap junctions and Panx in glial cells may contribute to development of migraine with aura, as they facilitate the spreading of signals between satellite glial cells, including $\mathrm{Ca}^{2+}$ waves [72].

$\mathrm{Ca}^{2+}$ spreading among glia and the aberrant transport of other ions may be associated in particular with a certain subtype of migraine with aura, called familial hemiplegic migraine (FHM). Despite the fact that neuron-glia co-sensitization occurs often in the course of migraine, in FHM the role of CGRP seems limited, as shown by the studies of Hansen et al. [73]. This fuels the suspicion that disturbances in ion transport within the brain arise from CGRP-independent processes [74].

\subsection{Familial Hemiplegic Migraine}

As the TGVS richly expresses ion channels [30], the hypothesis that migraine headache may be a result of dysregulated nerve excitation due to one or more channelopathies is an attractive one. Moreover, migraine shares clinical similarities with other channelopathies, e.g., myotonia or periodic paralysis including frequency and duration of attacks, paroxysmal character, triggers for attack, and gender-related predilection for attack [74]. Genetic studies of FHM have also substantiated the hypothesis that migraine, or at least aurae arise as a result of ionopathy.

FHM, the most severe subtype of MA, is characterized by the presence of temporary unilateral hemiparesis (numbness and/or motor weakness). Usually the symptoms of FHM start in the first or second decade of life. They may be accompanied by cerebellar atrophy and disturbances in cerebral blood flow. Less frequent are atypical attacks with cerebellar signs, encephalopathy, coma, prolonged hemiplegia, epileptic seizure, confusion, or fever, with full recovery or nystagmus and ataxia between attacks [75].

FHM is a rare, genetically heterogeneous disease, inherited in an autosomal dominant pattern with approximately $70-90 \%$ penetrance [76]. Three causative genes for FHM have been identified: CACNA1A (FHM type 1), ATP1A2 (FHM type 2) and SCN1A (FHM type 3) [77-79]. The $C A C N A 1 A$ gene encodes the $\alpha 1 \mathrm{~A}$ subunit of the $\mathrm{P} / \mathrm{Q}$-type high-voltage activated calcium channel. The ATP1A2 gene encodes the catalytic $\alpha 2$ subunit of $\mathrm{Na}^{+} / \mathrm{K}^{+}$ ATPase, which is exclusively expressed in astrocytes where it maintains the electrochemical gradient of $\mathrm{Na}^{+}$and $\mathrm{K}^{+}$ions essential for transport of $\mathrm{Ca}^{2+}$ and glutamate. The $\mathrm{Na}^{+} / \mathrm{K}^{+}$ ATPase also regulates the reuptake of $\mathrm{K}^{+}$and glutamate. The elevated level of $\mathrm{K}+$ due to FHM2 mutations triggers CSD [80]. The SCN1A gene encodes the $\alpha$ subunit of the neuronal voltage-gated sodium channel $\left(\mathrm{Na}_{\mathrm{v}} 1.1\right) . \mathrm{Na}_{\mathrm{v}} 1.1$ is mainly expressed in the cerebral cortex 
and spinal cord where it is responsible for the generation and propagation of action potentials. Mutations in FHM genes occur also in epileptic patients [81].

\section{Structure and Functions of CaV2.1}

Voltage-dependent $\mathrm{Ca}^{2+}$ channels are multiprotein complexes consisting of $\alpha 1, \alpha 2 \delta$, $\beta$ and $\gamma$ subunits [24]. The structural and functional diversity of VGCCs results from the multiple isoforms of each subunit, especially $\alpha 1$, different gating kinetics, and the many proteins with which they interact, often via transient, low-affinity molecular interactions (Table 1). CaV1, CaV2 and $\mathrm{CaV} 3$ are paralogs which have arisen through gene duplication events unaccompanied by speciation. CaV1 channels control synaptic integration and modulate NMDA receptor-mediated plasticity at the post-synapse, regulate enzyme activity and gene expression, and initiate excitation-contraction coupling. CaV2 channels mediate neurotransmission at the pre-synaptic active zone, while the CaV3 subfamily modulates the depolarization threshold for action potential initiation in cardiomyocytes and thalamic neurons. Both $\mathrm{CaV} 1$ and $\mathrm{CaV} 2$ are classified as high voltage-activated, while $\mathrm{CaV} 3 \mathrm{~s}$ are low voltage-activated channels $[24,29,82]$.

Of all of the culprits potentially implicated in migraine channelopathy, the P/Q-type CaV2.1 channel has received the most attention. CaV2.1 channels are present in presynaptic terminals and somatodendritic membranes in the brain and spinal cord [83]. Importantly, they are expressed in brain regions responsible for nociception or even strongly implicated in migraine pathogenesis e.g., TG and brainstem and control the release of vasoactive neuropeptides in the TGVS [84].

As presented in Figure 3, the $\alpha 1 \mathrm{~A}$ subunit of CaV2.1 is formed from four homologous domains (I-IV) consisting of six transmembrane regions (S1-S6). The S4 region constitutes the voltage sensor, while S5, the P-loop, and S6 form the pore region, which determines ion selectivity and conductance properties $[24,29,82]$.

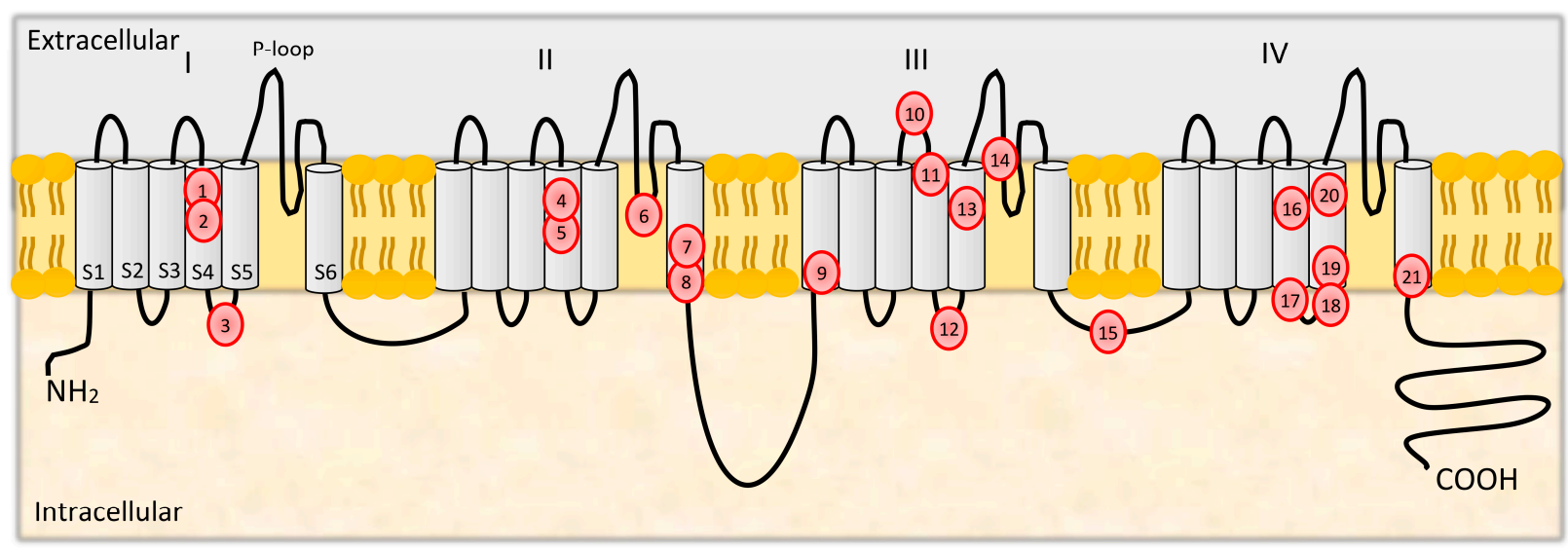

Figure 3. Locations of FHM1 mutations in the secondary structure of the calcium channel $\alpha 2.1$ subunit. 1-R192Q, 2-R195K, 3-S218L, 4-V581M, 5-R583Q, 6-T666M, 7-V714A, 8-D715E, 9-Y1246C, 10-K1336E, 11-R1347Q, 12-C1370Y, 13-Y1385C, 14-V1457L, 15-C1535S, 16-R1668W, 17-L1682P, 18-W1684R, 19-V1696I, 20-I1710T, 21-I1811L. I-IVnumber of extracellular loop.

CaV2.1 channels control action-potential evoked neurotransmitter release, by triggering activation of the exocytotic machinery at the pre-synapse [25]. CaV2.1s are able to interact with numerous $\mathrm{Ca}^{2+}$-binding proteins [24] and maintain short-term plasticity via $\mathrm{Ca}^{2+}$-dependent inactivation and $\mathrm{Ca}^{2+}$-dependent facilitation. CaV2.1 channels are also involved in local excitability of neurons, $\mathrm{Ca}^{2+}$ signaling, cell survival or gene expression [85]. Remarkably, CaV2.1 channels facilitate both fast neurotransmission and modulation of neuromuscular transmission of acetylcholine mediated by muscarinic M1 and M2 receptors and protein kinases A and C $[86,87]$. 


\subsection{Mutations in CACNA1A}

The CACNA1A gene consists of 47 exons and is located on chromosome 19p13. Age and gender-dependent alternative splice variants of exon 37 were found, which correspond to differences in channel kinetics and confer subfunctionalities to isoforms expressed in different brain regions [88].

Mutations in CACNA1A are associated with a few neurological diseases, including FHM, episodic ataxia type 2 (EA2), spinocerebellar ataxia type 6 (SCA6) and nonprogressive congenital ataxia (NPCA), and epilepsy [89]. Patients with FHM may present with symptoms of ataxia. Mutations in FHM genes are not found in common forms of MA and MO. CACNA1A mutations are responsible for about half of FHM cases. 21 FHM1 mutations were identified, all of them missense mutations leading to substitutions of amino acids in functional regions of the CaV2.1 channel, with the majority occurring in transmembrane segments of the $\alpha_{1}$ subunit (Figure 3).

Generally, different mutations are associated with pure FHM1 and FHM1 with cerebellar symptoms. For example, the R192Q mutation is responsible for a mild form of FHM1, whereas the S218L mutation causes a severe, often lethal phenotype [90]. Moreover, individuals with the same mutation may differ in terms of clinical symptoms, which suggests that epigenetic and environmental factors may be involved in determining phenotype (Table 1) [75].

Mutations in CACNA1A may be divided into three groups: gain of function, loss of function, or biallelic mutations. Half of FHM1 cases are caused by gain of function mutations. 13 of FHM1 mutations (R192Q, S218L, R583Q, T666M, V714A, D715E, Y1246C, K1336E, V1457L, W1684R, V1696I, I1710T, I1811L) were investigated in heterologous expression systems expressing recombinant CaV2.1 channels [105-117]; some of them (R192Q, S218L, T666M, V714A, I1811L) were also studied in neurons from CaV2.1-/ - mice expressing human CaV2.1 $\alpha 1$ subunits [108,111,118-120].

Studies on the HEK293 cell line [106] as well as on CaV2.1- / - neurons [108] evidenced that there is a decreased density of functional CaV2.1 in FHM1 mutant cells as compared to WT. This, however, has been rationalized as an artifact of overexpression post-transfection insofar as decreased numbers of functional channels were not observed when hCaV2.1 were expressed endogenously in knock-in mice [25]. Nonetheless, other studies on CaV2.1 - / - neurons found no differences in synaptic strength $[118,119]$. Further, CaV2.1-/+ mice have a reduced response to neuroinflammatory and neuropathic pain due to having roughly half the number of $\mathrm{CaV} 2.1$ channels, albeit in an age-dependent manner. This is compatible with the idea that CaV2.1 channels may be pronociceptive in terms of inflammation and neuropathic pain and antinociceptive in response to acute non-injurious noxious thermal stimuli.

CACNA1A mutations result in a wide spectrum of consequences including increased channel open probability, a lower voltage of activation leading to enhanced $\mathrm{Ca}^{2+}$ influx, reduced channel inhibition by G-protein $\beta \gamma$ heterodimers, altered synaptic morphology, excitation-inhibition imbalance and enhanced glutamate release. According to in vitro models of CSD, the increased glutamate release and interaction between glutamate and preand postsynaptic glutamate NMDA receptors may facilitate CSD. Importantly, CACNA1A mutations promoting increased $\mathrm{Ca}^{2+}$ influx seem to selectively capacitate glutamate release at pyramidal neurons, without altering fast-spiking inhibitory interneurons [117]. Further, the excitotoxic effects of glutamate on neuronal and glial cells have been shown to alter brain energy metabolism [117,120,121]. A study by Eikermann-Haerter et al. [115] showed that mice expressing the R192Q CACNA1 mutation were more sensitive to CSD than those bearing the S218L variant. Moreover, female mutant mice were more susceptible to CSD and neurological deficits than males. The R192Q mouse model pointed not only to a decreased threshold for CSD but also increased CaV2.1 current density [122]. Susceptibility to CSD can also be heightened by female hormones and allele dosage. In addition, FHM1 mice showed greater oxygen consumption leading to tissue anoxia, which may be responsible for prolonged aura [117]. 
Table 1. Clinical presentation of CACNA1 mutation in FHM.

\begin{tabular}{|c|c|c|c|c|}
\hline Mutation & Location & Population & Phenotypic Spectrum & References \\
\hline $\begin{array}{c}\mathrm{R} 192 \mathrm{Q} \\
\mathrm{rs} 121908211\end{array}$ & exon 4 & Italian family & No data & Ophoff et al. [77] \\
\hline $\begin{array}{c}\text { R195K } \\
\text { rs121908222 }\end{array}$ & exon 4 & French family & FHM without cerebellar signs & Ducros et al. [75] \\
\hline $\begin{array}{l}\text { S218L } \\
\text { rs121908225 }\end{array}$ & exon 5 & $\begin{array}{l}\text { British and Australian } \\
\text { families, } \\
\text { Malaysian family }\end{array}$ & $\begin{array}{l}\text { Minor head trauma-triggered delayed severe } \\
\text { cerebral edema and coma; childhood seizures }\end{array}$ & $\begin{array}{l}\text { Kors et al. [90] } \\
\text { Chan et al. [91] }\end{array}$ \\
\hline V581M & exon 13 & German family & $\begin{array}{c}\text { FHM with cerebellar } \\
\text { dysfunction and late-onset cognitive decline }\end{array}$ & Freilinger et al. [92] \\
\hline $\begin{array}{l}\mathrm{R} 583 \mathrm{Q} \\
\mathrm{rs} 121908217\end{array}$ & exon 13 & $\begin{array}{l}\text { Italian family, } \\
\text { Dutch patient, } \\
\text { Portuguese family, } \\
\text { Dutch patient }\end{array}$ & $\begin{array}{l}\text { FHM with consciousness and fever lasting } \\
\text { several days, late-onset cerebellar ataxia and } \\
\text { cerebellar atrophy; symptoms triggered by } \\
\text { minor head trauma; sporadic hemiplegic } \\
\text { migraine without cerebellar signs, age at onset } \\
13 \text { years }\end{array}$ & $\begin{array}{l}\text { Battistini et al. [93] } \\
\text { Terwindt et al. [94] } \\
\text { Alonso et al. [95] } \\
\text { de Vries et al. [96] }\end{array}$ \\
\hline $\begin{array}{c}\text { T666M } \\
\text { rs121908212 }\end{array}$ & exon 16 & $\begin{array}{l}\text { American family, } \\
\text { Australian family, } \\
\text { French families, } \\
\text { Dutch patient, } \\
\text { Dutch families }\end{array}$ & $\begin{array}{c}\text { Age at onset between } 2 \text { and } 22 \text { years; FHM with } \\
\text { progressive cerebellar ataxia; sporadic } \\
\text { hemiplegic migraine; progressive } \\
\text { cognitive dysfunction }\end{array}$ & $\begin{array}{l}\text { Ophoff et al. [77] } \\
\text { Friend et al. [97] } \\
\text { Ducros et al. [98] } \\
\text { Terwindt et al. [94] } \\
\text { Kors et al. [99] }\end{array}$ \\
\hline $\begin{array}{c}\text { V714A } \\
\text { rs121908213 }\end{array}$ & exon 17 & British family & Age at onset between 10 and 21 years & Ophoff et al. [77] \\
\hline $\begin{array}{c}\text { D715E } \\
\text { rs121908218 }\end{array}$ & exon 17 & French family & FHM with progressive cerebellar ataxia & Ducros et al. [98] \\
\hline K1336E & exon 25 & French family & FHM without cerebellar signs & Ducros et al. [75] \\
\hline $\begin{array}{l}\mathrm{R} 1347 \mathrm{Q} \\
\mathrm{rs} 121908230\end{array}$ & exon 25 & Dutch families & $\begin{array}{l}\text { Wide clinical spectrum ranging from (trauma } \\
\text { triggered) hemiplegic migraine with and } \\
\text { without ataxia, loss of consciousness and } \\
\text { epilepsy, early age at onset (usually before the } \\
\text { age of } 3 \text { ) }\end{array}$ & Stam et al. [100] \\
\hline $\begin{array}{c}\text { Y1385C } \\
\text { rs121908219 }\end{array}$ & exon 26 & French patients & $\begin{array}{l}\text { FHM with cerebellar signs, coma, hyperthermia, } \\
\text { meningeal signs, and partial seizure, }\end{array}$ & $\begin{array}{l}\text { Vahedi et al. [101] } \\
\text { Ducros et al. [75] }\end{array}$ \\
\hline $\begin{array}{l}\text { V1457L } \\
\text { rs121908237 }\end{array}$ & exon 27 & Italian family & $\begin{array}{l}\text { Mean age at onset } 34 \text { years, various degrees of } \\
\text { aphasia congruent with the hemispheric } \\
\text { dominance, without cerebellar ataxia or coma }\end{array}$ & Carrera et al. [102] \\
\hline R1668W & exon 32 & French family & FHM with or without cerebellar signs & Ducros et al. [75] \\
\hline W1684R & exon 32 & French family & FHM with cerebellar signs & Ducros et al. [75] \\
\hline V1696I & exon 33 & French family & FHM without cerebellar signs & Ducros et al. [75] \\
\hline $\begin{array}{c}\mathrm{I} 1710 \mathrm{~T} \\
\mathrm{rs} 121909326\end{array}$ & exon 33 & Dutch family & $\begin{array}{l}\text { FHM with childhood-onset of cerebellar ataxia } \\
\text { (SCA6), childhood complex partial and } \\
\text { generalized tonic-clonic seizures that occurred } \\
\text { independently of the FHM attacks }\end{array}$ & Kors et al. [103] \\
\hline $\begin{array}{l}\text { I1811L } \\
\text { rs121908214 }\end{array}$ & exon 36 & $\begin{array}{l}\text { Dutch and American } \\
\text { families }\end{array}$ & $\begin{array}{l}\text { Only one family displayed cerebellar atrophy } \\
\text { and in that family only some members } \\
\text { were affected }\end{array}$ & Ophoff et al. [77] \\
\hline $\begin{array}{l}\text { 18.2-kb } \\
\text { deletion }\end{array}$ & exons $39-47$ & $\begin{array}{l}\text { Irish, Indian, and } \\
\text { Danish patients }\end{array}$ & $\begin{array}{l}\text { FHM with or without ataxia, no seizures, no } \\
\text { family history }\end{array}$ & Labrum et al. [104] \\
\hline
\end{tabular}




\subsection{Calcium-Related Therapeutics in Migraine}

Migraine pharmacotherapy includes prophylactic agents taken every day (e.g., antidepressants and antiepileptic drugs) and agents taken at headache onset (e.g., triptans). Nonetheless, migraine patients typically migrate to analgesics, typically nonsteroidal antiinflammatory drugs (NSAIDs) available without prescription, despite mixed reports over their efficacy. Unfortunately, triptans, selective 5-HT1B/1D receptor agonists, which make up $80 \%$ of prescribed medications, proved to be effective in only $60 \%$ of migraine patients not responding to NSAIDs [123-125].

Unfortunately, most drugs currently in use do not prevent the recurrence of migraine attacks. Thus, migraine may be the cause of numerous absences at school, or at work. It was calculated that the costs of absenteeism from work due to migraines are much higher than the costs of its treatment. Important also is the fact that $3-4$ times more funds are spent for the treatment of chronic migraine in comparison with the episodic subtype. It is estimated that in the USA the annual total costs incurred for migraine, taking into account both the treatment, as well as losses due to absence from work add up to as much as 13 billion USD [126]. The lack of efficacious analgesics or means to prevent migraine recurrence in many patients has created a need for finding novel therapeutics.

Currently, there are no selective small molecule inhibitors of CaV2.1. Only two peptide toxins are selective for CaV2.1: $\omega$-agatoxin IVA and $\omega$-agatoxin IVB isolated from the venom of American funnel web spider A. aperta. Both $\omega$-agatoxins bind on the outside of the pore region of $\alpha 1$ a subunit of $\mathrm{CaV} 2.1$ but have different kinetics: blocking by $\omega$-agatoxin IVB is eightfold slower than IVA [127]. However, there are drugs that are not selective for but act also at CaV2.1 and show clinical efficacy in patients with FHM1 including flunarizine and the non-dihydropyridine verapamil [128].

New targets for migraine therapy may focused on different $\mathrm{Ca}^{2+}$ channels. One class worth noting is acid-sensing ion channels (ASICs), among which the ASIC1 predominates in the CNS. ASIC1 channels are responsible for enhancing $\mathrm{Ca}^{2+}$ permeability and pain signaling [129] and their overexpression has been found in chronic inflammatory and neuropathic models [130]. How ASICs are implicated in migraine pathogenesis remains largely unknown. Still, ASICs are activated by decreases in $\mathrm{pH}$ regulated in part by serotonin (5-HT) and nerve growth factor (NGF), changes in both of which are observed in migraine patients $[131,132]$. Secondly, ASIC1a is overexpressed in hypothalamic orexinergic neurons thought to be involved in migraine pathophysiology. Finally, lower $\mathrm{pH}$ secondary to ASIC activation may initiate or propagate CSD $[129,132]$. Corroborating this hypothesis, a study using experimental models showed that both amiloride (a nonselective blocker of ASICs) and tarantula toxin PcTx1 (a selective blocker of ASIC1a) inhibited CSD [133].

\section{Conclusions}

Migraine is a multifactorial neurological disease whose pathogenesis has not been fully elucidated. Although numerous dysregulated processes likely converge to manifest as migraine, disturbances in the distribution of various ions between extracellular and intracellular compartments seem to be a common denominator in the pathophysiology of the disease. Migraine "ionopathy" likely derives from one or multiple channelopathies which may be inherited e.g., mutations in CACNA1A and TRPA1, or result from the effects of toxic environmental factors. Certain parts of the brain appear particularly impacted by migraine-associated channelopathies. The TG, which is the major afferent pathway for pain signals from cranial vessels and dura mater, is implicated in migraine pathogenesis largely owing to its release of neuropeptides such as CGRP. CGRP is one of the most important molecules involved in neuron-glial communication, whose breakdown is related to the propagation of migraine pain and the sensitization of neurons which likely precedes the progression from episodic to chronic migraine. How calcium channelopathies impact CGRP pathways however, remains largely unknown. CSD, a purportedly non-synaptic phenomenon, and gap-junctional interactions also play a role in MA by driving aberrant neuron-neuron and neuron-glia signal propagation. As is the case with other neurologi- 
cal disorders, the complex and still poorly understood pathogenesis of migraine makes treatment difficult. Nonetheless, the pivotal role of CGRP in the disease has made it a prominent therapeutic target.

Author Contributions: M.K., M.P., T.P., J.D.; writing—original draft preparation, W.K.; investigation, J.D.; investigation. All authors have read and agreed to the published version of the manuscript.

Funding: This work was supported by the grant of NCBiR (European Union), No. POWR.03.01.00-00-T006/18-00.

Institutional Review Board Statement: Not applicable.

Informed Consent Statement: Not applicable.

Data Availability Statement: Not applicable.

Conflicts of Interest: The authors declare no conflict of interest.

\section{References}

1. Bolay, H.; Ozge, A.; Saginc, P.; Orekici, G.; Uludüz, D.; Yalın, O.; Siva, A.; Bıçakçi, S.; Karakurum, B.; Öztürk, M. Gender influences headache characteristics with increasing age in migraine patients. Cephalalgia 2015, 35, 792-800. [CrossRef]

2. Silberstein, S.D. Migraine. Lancet 2004, 363, 381-391. [CrossRef]

3. World Health Organization. Atlas of Headache Disorders and Resources in the World 2011; World Health Organisation: Geneva, Switzerland, 2011.

4. Vos, T.; Flaxman, A.D.; Naghavi, M.; Lozano, R.; Michaud, C.; Ezzati, M.; Shibuya, K.A.; Salomon, J.; Abdalla, S.; Aboyans, V.; et al. Years lived with disability (YLDs) for 1160 sequelae of 289 diseases and injuries 1990-2010: A systematic analysis for the Global Burden of Disease Study 2010. Lancet 2012, 380, 2163-2196. [CrossRef]

5. Simon, R.P.; Aminoff, M.J.; Greenberg, D.A. Clinical Neurology, 7th ed.; McGraw-Hill Professional Publishing: New York, NY, USA, 2009; Available online: http:/ / public.ebookcentral.proquest.com/choice/publicfullrecord.aspx? $\mathrm{p}=4667887$ (accessed on 30 October 2020).

6. Viana, M.; Sprenger, T.; Andelova, M.; Goadsby, P.J. The typical duration of migraine aura: A systematic review. Cephalalgia 2013, 33, 483-490. [CrossRef]

7. Headache Classification Committee of the International Headache Society (IHS). The International Classification of Headache Disorders; (beta version), 3rd ed. Cephalalgia 2013, 33, 629-808. [CrossRef]

8. Headache Classification Committee of the International Headache Society (IHS). The International Classification Of Headache Disorders. 3rd edition. Cephalalgia 2018, 38, 1-211. [CrossRef]

9. Menken, M.; Munsat, T.L.; Toole, J.F. The global burden of disease study: Implications for neurology. Arch. Neurol. 2000, 57, 418. [CrossRef]

10. Pietrobon, D. Calcium channels and migraine. Biochim. Biophys. Acta (BBA) Biomembr. 2013, 1828, 1655-1665. [CrossRef]

11. May, A.; Goadsby, P.J. The Trigeminovascular System in Humans: Pathophysiologic Implications for Primary Headache Syndromes of the Neural Influences on the Cerebral Circulation. Br. J. Pharmacol. 1999, 19, 115-127. [CrossRef]

12. Eftekhari, S.; Salvatore, C.A.; Johansson, S.; Chen, T.-B.; Zeng, Z.; Edvinsson, L. Localization of CGRP, CGRP receptor, PACAP and glutamate in trigeminal ganglion. Relation to the blood-brain barrier. Brain Res. 2015, 1600, 93-109. [CrossRef]

13. Leao, A.A.P. Spreading depression of activity in the cerebral cortex. J. Neurophysiol. 1944, 7, 359-390. [CrossRef]

14. Charles, A.C.; Baca, S.M. Cortical spreading depression and migraine. Nat. Rev. Neurol. 2013, 9, 637-644. [CrossRef] [PubMed]

15. Hansen, J.M.; Baca, S.M.; VanValkenburgh, P.; Charles, A. Distinctive anatomical and physiological features of migraine aura revealed by 18 years of recording. Brain 2013, 136, 3589-3595. [CrossRef]

16. Goadsby, P.J.; Edvinsson, L.; Ekman, R. Release of vasoactive peptides in the extracerebral circulation of hu-mans and the cat during activation of the trigeminovascular system. Ann. Neurol. 1988, 23, 193-196. [CrossRef] [PubMed]

17. Bolay, H.; Reuter, U.; Dunn, A.K.; Huang, Z.; Boas, D.A.; Moskowitz, M.A. Intrinsic brain activity triggers trigeminal meningeal afferents in a migraine model. Nat. Med. 2002, 8, 136-142. [CrossRef]

18. Zhang, X.; Levy, D.; Kainz, V.; Noseda, R.; Jakubowski, M.; Burstein, R. Activation of central trigeminovascular neurons by cortical spreading depression. Ann. Neurol. 2010, 69, 855-865. [CrossRef] [PubMed]

19. Gargus, J.J. Genetic Calcium Signaling Abnormalities in the Central Nervous System: Seizures, Migraine, and Autism. Ann. N. Y. Acad. Sci. 2008, 1151, 133-156. [CrossRef] [PubMed]

20. Ducros, A.; Tournier-Lasserve, E.; Bousser, M.-G. The genetics of migraine. Lancet Neurol. 2002, 1, 285-293. [CrossRef]

21. Montagna, P. Migraine: A genetic disease? Neurol. Sci. 2008, 29, 47-51. [CrossRef]

22. Mulley, J.C.; Scheffer, I.E.; Petrou, S.; Dibbens, L.M.; Berkovic, S.F.; Harkin, L.A. SCN1A mutations and epilepsy. Hum. Mutat. 2005, 25, 535-542. [CrossRef]

23. Talavera, K.; Startek, J.B.; Alvarez-Collazo, J.; Boonen, B.; Alpizar, Y.A.; Sanchez, A.; Naert, R.; Nilius, B. Mammalian transient receptor potential trpa1 channels: From structure to disease. Physiol. Rev. 2020, 100, 725-803. [CrossRef] 
24. Piekut, T.; Wong, Y.Y.; Senatore, A.; Walker, E.S.; Smith, C.L.; Gauberg, J.; Harracksingh, A.N.; Lowden, C.; Novogradac, B.B.; Cheng, H.-Y.M.; et al. Early metazoan origin and multiple losses of a novel clade of rim presynaptic calcium channel scaffolding protein homologs. Genome Biol. Evol. 2020, 12, 1217-1239. [CrossRef]

25. Pietrobon, D. CaV2.1 channelopathies. Pflügers Archiv Eur. J. Physiol. 2010, 460, 375-393. [CrossRef]

26. Wild, V.; Messlinger, K.; Fischer, M.J. Hydrogen sulfide determines HNO-induced stimulation of trigeminal afferents. Neurosci. Lett. 2015, 602, 104-109. [CrossRef]

27. Kunkler, P.E.; Ballardl, C.J.; Oxford, G.S.; Hurley, J.H. TRPA1 receptors mediate environmental irritant-induced meningeal vasodilatation. Pain 2011, 152, 38-44. [CrossRef]

28. Nanou, E.; Catterall, W.A. Calcium channels, synaptic plasticity, and neuropsychiatric disease. Neuron $2018,98,466-481$. [CrossRef]

29. Catterall, W.A. Voltage-gated calcium channels. Handb. Cell Sign. 2010, 3, 897-909. [CrossRef]

30. Amrutkar, D.; Ploug, K.; Olesen, J.; Jansen-Olesen, I. Role for voltage gated calcium channels in calcitonin gene-related peptide release in the rat trigeminovascular system. Neuroscience 2011, 172, 510-517. [CrossRef] [PubMed]

31. Yin, P.; Anttila, V.; Siewert, K.M.; Palotie, A.; Smith, G.D.; Voight, B.F. Serum calcium and risk of migraine: A Mendelian randomization study. Hum. Mol. Genet. 2016, 26, 820-828. [CrossRef] [PubMed]

32. Rau, J.C.; Dodick, D.W. Other preventive anti-migraine treatments: Ace inhibitors, arbs, calcium channel blockers, serotonin antagonists, and nmda receptor antagonists. Curr. Treat. Options Neurol. 2019, 21, 17. [CrossRef] [PubMed]

33. Edvinsson, L. Functional role of perivascular peptides in the control of cerebral circulation. Trends Neurosci. 1985, 8, 126-131. [CrossRef]

34. Eftekhari, S.; Salvatore, C.; Calamari, A.; Kane, S.; Tajti, J.; Edvinsson, L. Differential distribution of calcitonin gene-related peptide and its receptor components in the human trigeminal ganglion. Neuroscience 2010, 169, 683-696. [CrossRef] [PubMed]

35. Mulderry, P.K.; Ghatei, M.A.; Spokes, R.A.; Jones, P.M.; Pierson, A.M.; Hamid, Q.A.; Kanse, S.; Amara, S.G.; Burrin, J.M.; Legon, S.; et al. Differential expression of a-CGRP and b-CGRP by primary sensory neurons and enteric au-tonomic neurons of the rat. Neuroscience 1988, 25, 195-205.

36. Thomsen, L.; Kruuse, C.; Iversen, H.K.; Olesen, J. A nitric oxide donor (nitroglycerin) triggers genuine migraine attacks. Eur. J. Neurol. 1994, 1, 73-80. [CrossRef]

37. Weidner, C.; Klede, M.; Rukwied, R.; Lischetzki, G.; Neisius, U.; Schmelz, M.; Skov, P.S.; Petersen, L.J. Acute effects of substance p and calcitonin gene-related peptide in human skin-A microdialysis study. J. Investig. Dermatol. 2000, 115, 1015-1020. [CrossRef]

38. Guo, S.; Vollesen, A.L.; Olesen, J.; Ashina, M. Premonitory and nonheadache symptoms induced by CGRP and PACAP38 in patients with migraine. Pain 2016, 157, 2773-2781. [CrossRef]

39. Goadsby, P.J.; Edvinsson, L.; Ekman, R. Vasoactive peptide release in the extracerebral circulation of humans during migraine headache. Ann. Neurol. 1990, 28, 183-187. [CrossRef]

40. Goadsby, P.J.; Edvinsson, L. The trigeminovascular system and migraine: Studies characterizing cerebrovascular and neuropeptide changes seen in humans and cats. Ann. Neurol. 1993, 33, 48-56. [CrossRef] [PubMed]

41. Cernuda-Morollón, E.; Larrosa, D.; Ramón, C.; Vega, J.; Martínez-Camblor, P.; Pascual, J. Interictal increase of CGRP levels in peripheral blood as a biomarker for chronic migraine. Neurology 2013, 81, 1191-1196. [CrossRef]

42. Juhasz, G.; Zsombok, T.; Jakab, B.; Nemeth, J.; Szolcsanyi, J.; Bagdy, G. Sumatriptan causes parallel decrease in plasma calcitonin gene-related peptide (Cgrp) Concentration and migraine headache during nitroglycerin induced migraine attack. Cephalalgia 2005, 25, 179-183. [CrossRef]

43. Cady, R.K.; Vause, C.V.; Ho, T.W.; Bigal, M.E.; Durham, P.L. Elevated saliva calcitonin gene-related peptide levels during acute migraine predict therapeutic response to rizatriptan. Headache: J. Head Face Pain 2009, 49, 1258-1266. [CrossRef]

44. Ho, T.W.; Olesen, J.; Dodick, D.W.; Kost, J.; Lines, C.; Ferrari, M.D. Antimigraine efficacy of telcagepant based on patient's historical triptan response. Headache 2011, 51, 64-72. [CrossRef] [PubMed]

45. Hoffmann, J.; Goadsby, P.J. New agents for acute treatment of migraine: CGRP receptor antagonists, iNOS inhibitors. Curr. Treat. Options Neurol. 2011, 14, 50-59. [CrossRef] [PubMed]

46. Olesen, J.; Diener, H.-C.; Husstedt, I.W.; Goadsby, P.J.; Hall, D.; Meier, U.; Pollentier, S.; Lesko, L.M. Calcitonin gene-related peptide receptor antagonist bibn 4096 BS for the acute treatment of migraine. N. Engl. J. Med. 2004, 350, 1104-1110. [CrossRef] [PubMed]

47. Silberstein, S.D. Emerging target-based paradigms to prevent and treat migraine. Clin. Pharmacol. Ther. 2013, 93, 78-85. [CrossRef] [PubMed]

48. Voss, T.; Lipton, R.B.; Dodick, D.W.; Dupre, N.; Ge, J.Y.; Bachman, R.; Assaid, C.; Aurora, S.K.; Michelson, D.A. phase IIb randomized, double-blind, placebo-controlled trial of ubrogepant for the acute treatment of mi-graine. Cephalalgia 2016, 36, 887-898. [CrossRef]

49. Diener, H.-C.; Barbanti, P.; Dahlöf, C.; Reuter, U.; Habeck, J.; Podhorna, J. BI 44370 TA, an oral CGRP antagonist for the treatment of acute migraine attacks: Results from a phase II study. Cephalalgia 2011, 31, 573-584. [CrossRef]

50. Marcus, R.; Goadsby, P.J.; Dodick, D.; Stock, D.; Manos, G.; Fischer, T.Z. BMS-927711 for the acute treatment of migraine: A double-blind, randomized, placebo controlled, dose-ranging trial. Cephalalgia 2014, 34, 114-125. [CrossRef]

51. Stauffer, V.L.; Dodick, D.W.; Zhang, Q.; Carter, J.N.; Ailani, J.; Conley, R.R. Evaluation of galcanezumab for the prevention of episodic migraine: The EVOLVE-1 randomized clinical trial. JAMA Neurol. 2018, 75, 1080-1088. [CrossRef] 
52. Skljarevski, V.; Matharu, M.; Millen, A.B.; Ossipov, M.H.; Kim, B.-K.; Yang, J.Y. Efficacy and safety of galcanezumab for the prevention of episodic migraine: Results of the EVOLVE-2 Phase 3 randomized controlled clinical trial. Cephalalgia 2018, 38, 1442-1454. [CrossRef]

53. Dodick, D.W.; Goadsby, P.J.; Spierings, E.L.H.; Scherer, J.C.; Sweeney, S.P.; Grayzel, D.S. Safety and efficacy of LY2951742, a monoclonal antibody to calcitonin gene-related peptide, for the prevention of migraine: A phase 2, randomised, double-blind, placebo-controlled study. Lancet Neurol. 2014, 13, 885-892. [CrossRef]

54. Detke, H.C.; Goadsby, P.J.; Wang, S.; Friedman, D.I.; Selzler, K.J.; Aurora, S.K. Galcanezumab in chronic migraine: The randomized, double-blind, placebo-controlled REGAIN study. Neurology 2018, 91, e2211-e2221. [CrossRef] [PubMed]

55. Bigal, E.M.; Dodick, D.W.; Rapoport, A.M.; Silberstein, S.D.; Ma, Y.; Yang, R.; Loupe, P.S.; Burstein, R.; Newman, L.C.; Lipton, R.B. Safety, tolerability, and efficacy of TEV-48125 for preventive treatment of high-frequency episodic migraine: A multicentre, randomised, double-blind, placebo-controlled, phase 2b study. Lancet Neurol. 2015, 14, 1081-1090. [CrossRef]

56. Dodick, D.W.; Goadsby, P.J.; Silberstein, S.D.; Lipton, R.B.; Olesen, J.; Ashina, M.; Wilks, K.; Kudrow, D.; Kroll, R.; Kohrman, B.; et al. Safety and efficacy of ALD403, an antibody to calcitonin gene-related peptide, for the prevention of frequent episodic migraine: A randomised, double-blind, placebo-controlled, exploratory phase 2 trial. Lancet Neurol. 2014, 13, $1100-1107$. [CrossRef]

57. Sun, H.; Dodick, D.W.; Silberstein, S.; Goadsby, P.J.; Reuter, U.; Ashina, M.; Saper, J.; Cady, R.; Chon, Y.; Dietrich, J.; et al. Safety and efficacy of AMG 334 for prevention of episodic migraine: A randomised, double-blind, placebo-controlled, phase 2 trial. Lancet Neurol. 2016, 15, 382-390. [CrossRef]

58. Tepper, S.; Ashina, M.; Reuter, U.; Brandes, J.L.; Doležil, D.; Silberstein, S.; Winner, P.; Leonardi, D.; Mikol, D.; Lenz, R. Safety and efficacy of erenumab for preventive treatment of chronic migraine: A randomised, double-blind, placebo-controlled phase 2 trial. Lancet Neurol. 2017, 16, 425-434. [CrossRef]

59. Messlinger, K.; Balcziak, L.K.; Russo, A.F. Cross-talk signaling in the trigeminal ganglion: Role of neuropeptides and other mediators. J. Neural Transm. 2020, 127, 431-444. [CrossRef] [PubMed]

60. Dieterle, A.; Fischer, M.J.; Link, A.S.; Neuhuber, W.L.; Messlinger, K. Increase in CGRP- and nNOS-immunoreactive neurons in the rat trigeminal ganglion after infusion of an NO donor. Cephalalgia 2011, 31, 31-42. [CrossRef]

61. Iyengar, S.; Johnson, K.W.; Ossipov, M.H.; Aurora, S.K. CGRP and the trigeminal system in migraine. Headache J. Head Face Pain 2019, 59, 659-681. [CrossRef]

62. Capuano, A.; De Corato, A.; Lisi, L.; Tringali, G.; Navarra, P.; Russo, C.D. Proinflammatory-activated trigeminal satellite cells promote neuronal sensitization: Relevance for migraine pathology. Mol. Pain 2009, 5, 43. [CrossRef]

63. De Corato, A.; Lisi, L.; Capuano, A.; Tringali, G.; Tramutola, A.; Navarra, P.; Russo, C.D. Trigeminal satellite cells express functional calcitonin gene-related peptide receptors, whose activation enhances interleukin-1beta pro-inflammatory effects. $J$. Neuroimmunol. 2011, 237, 39-46. [CrossRef]

64. Thalakoti, S.; Patil, V.V.; Damodaram, S.; Vause, C.V.; Langford, L.E.; Freeman, S.E.; Durham, P.L. Neuron-glia signaling in trigeminal ganglion: Implications for migraine pathology. Headache 2007, 47, 1008-1023. [CrossRef]

65. Bowen, E.J.; Schmidt, T.W.; Firm, C.S.; Russo, A.F.; Durham, P.L. Tumor necrosis factor-alpha stimulation of calcitonin gene-related peptide expression and secretion from rat trigeminal ganglion neurons. J. Neurochem. 2005, 96, 65-77. [CrossRef]

66. Kwok, Y.H.; Swift, J.E.; Gazerani, P.; Rolan, P. A double-blind, randomized, placebo-controlled pilot trial to determine the efficacy and safety of ibudilast, a potential glial attenuator, in chronic migraine. J. Pain Res. 2016, 9, 899-907. [CrossRef] [PubMed]

67. Durham, Z.L.; Hawkins, J.L.; Durham, P.L. Tumor necrosis factor-Alpha stimulates cytokine expression and transient sensitization of trigeminal nociceptive neurons. Arch. Oral Biol. 2017, 75, 100-106. [CrossRef] [PubMed]

68. Durham, P.L. Diverse physiological roles of calcitonin gene-related peptide in migraine pathology: Modulation of neuronal-glialimmune cells to promote peripheral and central sensitization. Curr. Pain Headache Rep. 2016, 20, 1-9. [CrossRef] [PubMed]

69. Cady, R.J.; Glenn, J.R.; Smith, K.M.; Durham, P.L. Calcitonin gene-related peptide promotes cellular changes in trigeminal neurons and glia implicated in peripheral and central sensitization. Mol. Pain. 2011, 7. [CrossRef]

70. Cornelison, L.E.; Hawkins, J.L.; Durham, P.L. Elevated levels of calcitonin gene-related peptide in upper spinal cord promotes sensitization of primary trigeminal nociceptive neurons. Neuroscience 2016, 339, 491-501. [CrossRef]

71. Weir, A.G.; Cader, M.Z. New directions in migraine. BMC Med. 2011, 9, 116. [CrossRef]

72. Spraya, D.C.; Hananib, M. Gap junctions, pannexins and pain. Neurosci. Lett. 2019, 695, 46-52. [CrossRef] [PubMed]

73. Hansen, J.M.; Thomsen, L.L.; Olesen, J.; Ashina, M. Calcitonin gene-related peptide does not cause the familial hemiplegic migraine phenotype. Neurology 2008, 71, 841-847. [CrossRef]

74. Ptáček, L.J. Channelopathies: Ion channel disorders of muscle as a paradigm for paroxysmal disorders of the nervous system. Neuromuscul. Disord. 1997, 7, 250-255. [CrossRef]

75. Ducros, A.; Denier, C.; Joutel, A.; Cecillon, M.; Lescoat, C.; Vahedi, K.; Darcel, F.; Vicaut, E.; Bousser, M.-G.; Tournier-Lasserve, E. The clinical spectrum of familial hemiplegic migraine associated with mutations in a neuronal calcium channel. N. Engl. J. Med. 2001, 345, 17-24. [CrossRef]

76. Goadsby, P.J.; Holland, P.R.; Martins-Oliveira, M.; Hoffmann, J.; Schankin, C.; Akerman, S. Pathophysiology of migraine: A disorder of sensory processing. Physiol. Rev. 2017, 97, 553-622. [CrossRef] 
77. Ophoff, A.R.; Terwindt, G.M.; Haan, J.; Lindhout, D.; van Ommen, G.-J.B.; Hofker, M.H.; Ferrari, M.D.; Frants, R.R.; Vergouwe, M.N.; van Eijk, R.; et al. Familial hemiplegic migraine and episodic ataxia type-2 are caused by mutations in the CA2+ channel gene CACNL1a4. Cell 1996, 87, 543-552. [CrossRef]

78. De Fusco, M.; Marconi, R.; Silvestri, L.; Atorino, L.; Rampoldi, L.; Morgante, L.; Ballabio, A.; Aridon, P.; Casari, G. Haploinsufficiency of ATP1A2 encoding the $\mathrm{Na}+/ \mathrm{K}+$ pump $\alpha 2$ subunit associated with familial hemiplegic migraine type 2. Nat. Genet. 2003, 33, 192-196. [CrossRef] [PubMed]

79. Dichgans, M.; Freilinger, T.; Eckstein, G.; Babini, E.; Lorenz-Depiereux, B.; Biskup, S.; Ferrari, M.D.; Herzog, J.; Maagdenberg, A.M.J.M.V.D.; Pusch, M.; et al. Mutation in the neuronal voltage-gated sodium channel SCN1A in familial hemiplegic migraine. Lancet 2005, 366, 371-377. [CrossRef]

80. Leo, L.; Gherardini, L.; Barone, V.; De Fusco, M.; Pietrobon, D.; Pizzorusso, T.; Casari, G. Increased susceptibility to cortical spreading depression in the mouse model of familial hemiplegic migraine type 2. PLoS Genet. 2011, 7, e1002129. [CrossRef] [PubMed]

81. Huang, Y.; Xiao, H.; Qin, X.; Nong, Y.; Zou, D.; Wu, Y. The genetic relationship between epilepsy and hemiplegic migraine. Neuropsychiatr. Dis. Treat. 2017, 13, 1175-1179. [CrossRef] [PubMed]

82. Urbano, F.J.; Pagani, M.R.; Uchitel, O.D. Calcium channels, neuromuscular synaptic transmission and neurological diseases. J. Neuroimmunol. 2008, 201-202, 136-144. [CrossRef] [PubMed]

83. Westenbroek, R.; Sakurai, T.; Elliott, E.; Hell, J.; Starr, T.; Snutch, T.; Catterall, W. Immunochemical identification and subcellular distribution of the alpha 1A subunits of brain calcium channels. J. Neurosci. 1995, 15, 6403-6418. [CrossRef]

84. Akerman, S.; Williamson, D.J.; Goadsby, P.J. Voltage-dependent calcium channels are involved in neurogenic dural vasodilatation via a presynaptic transmitter release mechanism: Voltage-dependent calcium channels. Br. J. Pharmacol. 2003, 140, 558-566. [CrossRef] [PubMed]

85. Pietrobon, D. Function and dysfunction of synaptic calcium channels: Insights from mouse models. Curr. Opin. Neurobiol. 2005, 15, 257-265. [CrossRef]

86. Santafé, M.M.; Salon, I.; Garcia, N.; Lanuza, M.A.; Uchitel, O.D.; Tomàs, J. Modulation of ACh release by presynaptic muscarinic autoreceptors in the neuromuscular junction of the newborn and adult rat: Muscarinic autoreceptors in neuromuscular transmission. Eur. J. Neurosci. 2003, 17, 119-127. [CrossRef] [PubMed]

87. Santafé, M.M.; Lanuza, M.A.; Garcia, N.; Tomàs, J. Muscarinic autoreceptors modulate transmitter release through protein kinase $\mathrm{C}$ and protein kinase $\mathrm{A}$ in the rat motor nerve terminal. Eur. J. Neurosci. 2006, 23, 2048-2056. [CrossRef] [PubMed]

88. Chang, S.Y.; Yong, T.F.; Yu, C.Y.; Liang, M.C.; Pletnikova, O.; Troncoso, J.C.; Burgunder, J.-M.; Soong, T.W. Age and genderdependent alternative splicing of P/Q-type calcium channel EF-hand. Neuroscience 2007, 145, 1026-1036. [CrossRef] [PubMed]

89. Travaglini, L.; Nardella, M.; Bellacchio, E.; D'Amico, A.; Capuano, A.; Frusciante, R.; Di Capua, M.; Cusmai, R.; Barresi, S.; Morlino, S.; et al. Missense mutations of CACNA1A are a frequent cause of autosomal dominant nonprogressive congenital ataxia. Eur. J. Paediatr. Neurol. 2017, 21, 450-456. [CrossRef] [PubMed]

90. Kors, E.E.; Terwindt, G.M.; Vermeulen, F.L.M.G.; Fitzsimons, R.B.; Jardine, P.E.; Heywood, P.; Love, S.; Maagdenberg, A.M.J.M.V.D.; Haan, J.; Frants, R.R.; et al. Delayed cerebral edema and fatal coma after minor head trauma: Role of the CACNA1A calcium channel subunit gene and relationship with familial hemiplegic migraine. Ann. Neurol. 2001, 49, 753-760. [CrossRef] [PubMed]

91. Chan, Y.-C.; Burgunder, J.-M.; Wilder-Smith, E.; Chew, S.-E.; Lam-Mok-Sing, K.M.; Sharma, V.; Ong, B.K. Electroencephalographic changes and seizures in familial hemiplegic migraine patients with the CACNA1A gene S218L mutation. J. Clin. Neurosci. 2008, 15, 891-894. [CrossRef]

92. Freilinger, T.; Ackl, N.; Ebert, A.; Schmidt, C.; Rautenstrauss, B.; Dichgans, M.; Danek, A. A novel mutation in CACNA1A associated with hemiplegic migraine, cerebellar dysfunction and late-onset cognitive decline. J. Neurol. Sci. 2011, 300, 160-163. [CrossRef] [PubMed]

93. Battistini, S.; Stenirri, S.; Piatti, M.; Gelfi, C.; Righetti, P.G.; Rocchi, R.; Giannini, F.; Battistini, N.; Guazzi, G.C.; Ferrari, M.; et al. A new CACNA1A gene mutation in acetazolamide-responsive familial hemiplegic migraine and ataxia. Neurology 1999, 53, 38. [CrossRef] [PubMed]

94. Terwindt, G.; Kors, E.; Haan, J.; Vermeulen, F.; Maagdenberg, A.V.D.; Frants, R.; Ferrari, M. Mutation analysis of the CACNA1A calcium channel subunit gene in 27 patients with sporadic hemiplegic migraine. Arch. Neurol. 2002, 59, 1016-1018. [CrossRef] [PubMed]

95. Alonso, I.; Barros, J.; Tuna, A.; Coelho, J.; Sequeiros, J.; Silveira, I.; Coutinho, P. Phenotypes of spinocerebellar ataxia type 6 and familial hemiplegic migraine caused by a unique CACNA1a missense mutation in patients from a large family. Arch. Neurol. 2003, 60, 610-614. [CrossRef] [PubMed]

96. de Vries, B.; Freilinger, T.; Vanmolkot, K.R.; Koenderink, J.B.; Stam, A.H.; Terwindt, G.M.; Babini, E.; van den Boogerd, E.H.; van den Heuvel, J.J.; Frants, R.R.; et al. Systematic analysis of three FHM genes in 39 sporadic patients with hemiplegic migraine. Neurology 2007, 69, 2170-2176. [CrossRef]

97. Friend, K.L.; Crimmins, D.; Phan, T.G.; Sue, C.M.; Colley, A.; Fung, V.S.; Morris, J.G.; Sutherland, G.R.; Richards, R.I. Detection of a novel missense mutation and second recurrent mutation in the CACNA1A gene in individuals with EA-2 and FHM. Hum. Genet. 1999, 105, 261-265. [CrossRef] [PubMed] 
98. Ducros, A.; Denier, C.; Hirsch, E.; Chedru, F.; Bisgård, C.; Lucotte, G.; Després, P.; Billard, C.; Barthez, M.; Ponsot, G.; et al. Recurrence of the T666M calcium channel CACNA1a gene mutation in familial hemiplegic migraine with progressive cerebellar ataxia. Am. J. Hum. Genet. 1999, 64, 89-98. [CrossRef] [PubMed]

99. Kors, E.E.; Haan, J.; Giffin, N.J.; Pazdera, L.; Schnittger, C.; Lennox, G.G.; Terwindt, G.M.; Vermeulen, F.L.; Van den Maagdenberg, A.M.; Frants, R.R.; et al. Expanding the phenotypic spectrum of the CACNA1A gene T666M mutation: A description of 5 families with familial hemiplegic migraine. Arch. Neurol. 2003, 60, 684-688. [CrossRef]

100. Stam, A.; Vanmolkot, K.; Kremer, H.; Gärtner, J.; Brown, J.; Leshinsky-Silver, E.; Gilad, R.; Kors, E.; Frankhuizen, W.; Ginjaar, H.; et al. CACNA1A R1347Q: A frequent recurrent mutation in hemiplegic migraine. Clin. Genet. 2008, 74, 481-485. [CrossRef] [PubMed]

101. Vahedi, K.; Denier, C.; Ducros, A.; Bousson, V.; Levy, C.; Chabriat, H.; Haguenau, M.; Tournier-Lasserve, E.; Bousser, M.G. CACNA1A gene de novo mutation causing hemiplegic migraine, coma, and cerebellar atrophy. Neurology 2000, 55, 1040-1042. [CrossRef]

102. Carrera, P.; Piatti, M.; Stenirri, S.; Grimaldi, L.M.E.; Marchioni, E.; Curcio, M.; Righetti, P.G.; Ferrari, M.; Gelfi, C. Genetic heterogeneity in Italian families with familial hemiplegic migraine. Neurology 1999, 53, 26. [CrossRef]

103. Kors, E.E.; Melberg, A.; Vanmolkot, K.R.J.; Kumlien, E.; Haan, J.; Raininko, R.; Flink, R.; Ginjaar, H.B.; Frants, R.R.; Ferrari, M.D.; et al. Childhood epilepsy, familial hemiplegic migraine, cerebellar ataxia, and a new CACNA1A mutation. Neurology 2004, 63, 1136-1137. [CrossRef]

104. Labrum, R.W.; Rajakulendran, S.; Graves, T.D.; Eunson, L.H.; Bevan, R.; Sweeney, M.G.; Hammans, S.R.; Tubridy, N.; Britton, T.; Carr, L.J.; et al. Large scale calcium channel gene rearrangements in episodic ataxia and hemiplegic migraine: Implications for diagnostic testing. J. Med Genet. 2009, 46, 786-791. [CrossRef]

105. Kraus, R.L.; Sinnegger, M.J.; Glossmann, H.; Hering, S.; Striessnig, J. Familial hemiplegic migraine mutations change $\alpha 1 \mathrm{~A}$ Ca 2+ Channel Kinetics. J. Biol. Chem. 1998, 273, 5586-5590. [CrossRef]

106. Hans, M.; Luvisetto, S.; Williams, M.E.; Spagnolo, M.; Urrutia, A.; Tottene, A.; Brust, P.F.; Johnson, E.C.; Harpold, M.M.; Stauderman, K.A.; et al. Functional consequences of mutations in the human $\alpha$ 1a calcium channel subunit linked to familial hemiplegic migraine. J. Neurosci. 1999, 19, 1610-1619. [CrossRef]

107. Stenirri, S.; Carrera, P.; Kraus, R.L.; Sinnegger, M.J.; Koschak, A.; Glossmann, H.; Striessnig, J. Three new familial hemiplegic migraine mutants affect P/Q-type CA2+ channel kinetics. J. Biol. Chem. 2000, 275, 9239-9243. [CrossRef]

108. Tottene, A.; Fellin, T.; Pagnutti, S.; Luvisetto, S.; Striessnig, J.; Fletcher, C.; Pietrobon, D. Familial hemiplegic mi-graine mutations increase Ca2+ influx through single human CaV2.1 channels and decrease maximal CaV2.1 current density in neurons. Proc. Natl. Acad. Sci. USA 2002, 99, 13284-13289. [CrossRef] [PubMed]

109. Melliti, K.; Grabner, M.; Seabrook, G.R. The familial hemiplegic migraine mutation R192q reduces G-protein-mediated inhibition of p/q-type (Ca v 2.1) calcium channels expressed in human embryonic kidney cells. J. Physiol. 2003, 546, 337-347. [CrossRef] [PubMed]

110. Müllner, C.; Broos, L.A.; van den Maagdenberg, A.M.; Striessnig, J. Familial hemiplegic migraine type 1 mutations k1336e, w1684r, and v1696i alter CA V 2.1 CA 2+ channel gating: Evidence for $\beta$-subunit isoform-specific effects. J. Biol. Chem. 2004, 279, 51844-51850. [CrossRef] [PubMed]

111. Tottene, A.; Pivotto, F.; Fellin, T.; Cesetti, T.; van den Maagdenberg, A.M.; Pietrobon, D. Specific kinetic alterations of human CA V 2.1 calcium channels produced by mutation s2181 causing familial hemiplegic migraine and delayed cerebral edema and coma after minor head trauma. J. Biol. Chem. 2005, 280, 17678-17686. [CrossRef]

112. Barrett, C.F.; Cao, Y.-Q.; Tsien, R.W. Gating deficiency in a familial hemiplegic migraine type 1 mutant P/Q-type calcium channel. J. Biol. Chem. 2005, 280, 24064-24071. [CrossRef] [PubMed]

113. Weiss, N.; Sandoval, A.; Felix, R.; Van den Maagdenberg, A.; De Waard, M. The S218L familial hemiplegic mi-graine mutation promotes deinhibition of Cav2.1 calcium channels during direct G-protein regulation. Pflüg Arch. 2008, 457, 315-326. [CrossRef] [PubMed]

114. Adams, P.J.; Garcia, E.; David, L.S.; Mulatz, K.J.; Spacey, S.D.; Snutch, T.P. Ca V 2.1 P/Q-type calcium channel alter-native splicing affects the functional impact of familial hemiplegic migraine mutations: Implications for calcium channelopathies. Channels 2009, 3, 110-121. [CrossRef]

115. Eikermann-Haerter, K.; Dileköz, E.; Kudo, C.; Savitz, S.I.; Waeber, C.; Baum, M.J.; Ferrari, M.D.; van den Maagden-berg, A.M.; Moskowitz, M.A.; Ayata, C. Genetic and hormonal factors modulate spreading depression and tran-sient hemiparesis in mouse models of familial hemiplegic migraine type 1. J. Clin. Invest. 2009, 119, 99-109.

116. Serra, S.A.; Fernàndez-Castillo, N.; Macaya, A.; Cormand, B.; Valverde, M.A.; Fernández-Fernández, J.M. The hem-iplegic migraine-associated Y1245C mutation in CACNA1A results in a gain of channel function due to its effect on the voltage sensor and G-protein-mediated inhibition. Pflüg Arch. 2009, 458, 489-502. [CrossRef] [PubMed]

117. Khennouf, L.; Gesslein, B.; Lind, B.L.; van den Maagdenberg, A.M.; Lauritzen, M. Activity-dependent calcium, oxygen, and vascular responses in a mouse model of familial hemiplegic migraine type 1: Calcium, oxygen and vascular responses in migraine. Ann. Neurol. 2016, 80, 219-232. [CrossRef]

118. Cao, Y.Q.; Piedras-Rentería, E.S.; Smith, G.B.; Chen, G.; Harata, N.C.; Tsien, R.W. Presynaptic Ca2+ Channels Com-pete for Channel Type-Preferring Slots in Altered Neurotransmission Arising from Ca2+ Channelopathy. Neuron 2004, 43, 387-400. [CrossRef] [PubMed] 
119. Cao, Y.-Q.; Tsien, R.W. Effects of familial hemiplegic migraine type 1 mutations on neuronal P/Q-type Ca2+ channel activity and inhibitory synaptic transmission. Proc. Natl. Acad. Sci. USA 2005, 102, 2590-2595. [CrossRef]

120. Tottene, A.; Conti, R.; Fabbro, A.; Vecchia, D.; Shapovalova, M.; Santello, M.; Maagdenberg, A.M.V.D.; Ferrari, M.D.; Pietrobon, D. Enhanced excitatory transmission at cortical synapses as the basis for facilitated spreading depression in CAV2.1 knockin migraine mice. Neuron 2009, 61, 762-773. [CrossRef] [PubMed]

121. Haan, J.; Kors, E.E.; Vanmolkot, K.R.; van den Maagdenberg, A.M.; Frants, R.R.; Ferrari, M.D. Migraine genetics: An up-date. Curr. Pain Headache Rep. 2005, 9, 213-220. [CrossRef]

122. van den Maagdenberg, A.M.; Pietrobon, D.; Pizzorusso, T.; Kaja, S.; Broos, L.A.; Cesetti, T.; van de Ven, R.C.; Tottene, A.; van der Kaa, J. A cacna1a knockin migraine mouse model with increased susceptibil-ity to cortical spreading depression. Neuron 2004, 41, 701-710. [CrossRef]

123. Smitherman, T.A.; Burch, R.; Sheikh, H.; Loder, E. The prevalence, impact, and treatment of migraine and SE-vere headaches in the United States: A review of statistics from national surveillance studies. Headache 2013, 53, 427-436. [CrossRef]

124. Antonaci, F.; Ghiotto, N.; Wu, S.; Pucci, E.; Costa, A. Recent advances in migraine therapy. SpringerPlus 2016, 5, 637. [CrossRef] [PubMed]

125. Diener, H.-C.; Dodick, D.W.; Goadsby, P.J.; Lipton, R.B.; Olesen, J.; Silberstein, S.D. Chronic migraine—classification, characteristics and treatment. Nat. Rev. Neurol. 2012, 8, 162-171. [CrossRef]

126. Burton, W.N.; Landy, S.H.; Downs, K.E.; Runken, M.C. The impact of migraine and the effect of migraine treat-ment on workplace productivity in the united states and suggestions for future research. Mayo Clin. Proc. 2009, 84, 436-445. [CrossRef]

127. Nimmrich, V.; Gross, G. P/Q-type calcium channel modulators: P/Q-type calcium channel blockers. Br. J. Pharmacol. 2012, 167, 741-759. [CrossRef] [PubMed]

128. Beswick, P. Progress in the discovery of Ca channel blockers for the treatment of pain. In Comprehensive Medicinal Chemistry III; Elsevier BV: Amsterdam, The Netherlands, 2017; pp. 65-130.

129. Dussor, G. ASICs as therapeutic targets for migraine. Neuropharmacology 2015, 94, 64-71. [CrossRef]

130. Mazzuca, M.; Heurteaux, C.; Alloui, A.; Diochot, S.; Baron, A.; Voilley, N.; Blondeau, N.; Escoubas, P.; Gélot, A.; Cupo, A.; et al. A tarantula peptide against pain via ASIC1a channels and opioid mechanisms. Nat. Neurosci. 2007, 10, 943-945. [CrossRef] [PubMed]

131. Sarchielli, P.; Alberti, A.; Floridi, A.; Gallai, V. Levels of nerve growth factor in cerebrospinal fluid of chronic daily headache patients. Neurology 2001, 57, 132-134. [CrossRef]

132. Kowalska, M.; Prendecki, M.; Kozubski, W.; Lianeri, M.; Dorszewska, J. Molecular factors in migraine. Oncotarget 2016, 7, 50708-50718. [CrossRef]

133. Holland, P.R.; Akerman, S.; Andreou, A.P.; Karsan, N.; Wemmie, J.A.; Goadsby, P.J. Acid-sensing ion channel 1: A novel therapeutic target for migraine with aura. Ann. Neurol. 2012, 72, 559-563. [CrossRef] 